\title{
Heavy Metal Geochemistry of Soils in Selected Industrial and Farmlands of Enugu State: A Preliminary Investigation
}

\author{
Iyi Emmanuel Chibuike, Ozoko Daniel Chukwuemeka \& Ezeh Christopher Chukwudi \\ Department of Geology and Mining \\ Faculty of Applied Natural Science \\ Enugu State University of Science and Technology, Enugu, Enugu State, Nigeria \\ Email: iyiemmanuel@yahoo.com
}

DOI: $10.31364 / S C I R J / v 7.16 .2019 . P 0619659$

http://dx.doi.org/10.31364/SCIRJ/v7.i6.2019.P0619659

\begin{abstract}
The present research was designed for the investigation of heavy metal geochemistry of soils in selected industrial and farmlands of Enugu State. Soil samples were randomly collected at depths of $0.5 \mathrm{~m}$ from 60 sites at dumpsites, industries, wetlands, mechanic workshops, roadsides, animal dungs and river beds during wet and dry seasons using soil auger and polythene bags. The soil samples were analyzed for $\mathrm{Fe}^{3+}, \mathrm{Mn}, \mathrm{As}, \mathrm{Pb}, \mathrm{Zn}, \mathrm{Cd}, \mathrm{Cr}, \mathrm{Ni}$ and $\mathrm{Cu}$ using standard analytical methods. The results show mean value of $\mathrm{Fe}^{3+}$ ranging from 515.62 to $107.8 \mathrm{mg} / \mathrm{kg}$ in the wet season and 578.7 to $107.8 \mathrm{mg} / \mathrm{kg}$ during the dry season. Mn varies between $83.5-18.05 \mathrm{mg} / \mathrm{kg}$ in the wet season and $101.9-18.1 \mathrm{mg} / \mathrm{kg}$ in the dry season. As range from $48.35-20.9 \mathrm{mg} / \mathrm{kg}$ during the wet season as well as $46.97-25.25 \mathrm{mg} / \mathrm{kg}$ during the dry season. Mean levels of $\mathrm{Pb}$ ranged from 106.6 to $51.3 \mathrm{mg} / \mathrm{kg}$ in the wet season and 96.1 to $43.8 \mathrm{mg} / \mathrm{kg}$ in the dry season. Zn concentration in the wet season varied between 425.05 and $228.95 \mathrm{mg} / \mathrm{kg}$, and is slightly lower than the dry season (432.2 and $190.0 \mathrm{mg} / \mathrm{kg}$ ), while Cd was found in trace amounts between 2.013 to $0.422 \mathrm{mg} / \mathrm{kg}$ in the wet season and is marginally higher than dry season $\left(2.002\right.$ to $0.422 \mathrm{mg} / \mathrm{kg}$ ). The mean values of $\mathrm{Fe}^{3+}, \mathrm{Mn}, \mathrm{As}$ and $\mathrm{Pb}$ for both wet and dry seasons in the study area have reached pollutant level based on FAO/WHO standards for industrial and agricultural soils. Furthermore, Pearson correlation matrix of the parameters show high positive correlation between $\mathrm{Mn}$ and Fe; $\mathrm{Zn}$ and Fe; $\mathrm{Zn}$ and $\mathrm{Mn}$; $\mathrm{Cu}$ and $\mathrm{Cd}$; as well as $\mathrm{Cu}$ and $\mathrm{Cr}$ for both seasons which indicates the strong relation between these variables and pointed out that soils' deterioration was associated with industrial and agricultural activities. However, there is a potential risk of poisoning of humans, animals and agricultural produce by heavy metals in the study area.
\end{abstract}

Key words: Heavy Metal, Contamination, Enugu State, Industrial, Soil

\section{INTRODUCTION}

Soils are the end point for heavy metals generated by anthropogenic factors (e.g., metal finishing, paint pigment, livestock wastewater, battery manufacturing, leather tanning, mining activities, municipal waste water sludges, urban composts, pesticides, phosphate fertilizers, vehicular exhaust, energy and fuel production, power transmission, automobile mechanic workshops, chemical lumps from industries and factories) and geogenic factors; including parent materials, the chemical and physical soil properties, metal speciation and climatic conditions (Elanzer et al., 2015; Nouri and Haddioui 2016). Soils, especially those found within agricultural and industrial sites are highly contaminated by heavy metals, including arsenic (As), iron $\left(\mathrm{Fe}^{3+}\right)$, manganese $(\mathrm{Mn})$ cadmium $(\mathrm{Cd})$, chromium $(\mathrm{Cr})$, copper $(\mathrm{Cu})$, lead $(\mathrm{Pb})$, nickel $(\mathrm{Ni})$, and zinc $(\mathrm{Zn})$. Human exposure to these metals can cause deadlier diseases like gastrointestinal, neurological, tumor, head stuffiness, muscular, congestion of nasal mucous membranes and pharynx, edema of eyelids, genetic and reproductive malfunctions (Zhao et al., 2012). Heavy metal soil contaminations have become a serious threat to the health of humans, animals and plants (Ahmadipour et al., 2014).

The rapid increase in urbanization, industrialization and ever-growing population nationwide in combination with the effects of increasing domestic, agricultural, municipal and industrial wastes has been reported by different authors as prior pollutant which pose a grievous threat to the environment (Kelly et al., 1996; Assah et al., 2003; Adewara and Akinolu 2007; Njoku and Onyeka 2007; Sharma et al., 2007; Osakwe 2010; Ekere and Ukoha, 2013). They also remarked that developing countries suffer from problems arising from industrial effluent and agricultural discharge into soils. Ottensen and Langedal (2001), worked on the chemical composition of urban surface soil in Trondheim, Noway, to determine whether stack emission from industrial sites, incinerators and crematoria, as well as road traffic have caused local elevated concentrations of certain elements. They reported that, $\mathrm{Cd}, \mathrm{Hg}, \mathrm{Pb}$, and $\mathrm{Zn}$ have contaminated the surface soils in the central and older parts of the city and along main roads. The most dominant sources 
were presumably automobile exhaust, tyre wear, and emission from hospital incinerators and crematorium. Xiangdong et al., (2010) studied metal contamination in urban soils of Hong Kong using a GIS-based approach. Using GIS spatial analysis methods, the majority of the hot-spot areas were identified to be road junctions and/or sites next to major roads, suggesting that vehicular emissions and the wear and tear of mechanical parts in vehicles may be the major sources of heavy metals in urban soils. Some hot-spot areas were located close to industrial sites, indicating that industrial activities may also contribute to the accumulation of heavy metals in urban soils. The analysis of $\mathrm{Pb}$ isotopic composition suggested strong influences of anthropogenic origins of $\mathrm{Pb}$ in these urban soils. Similarly, Okafor and Onwuka (2013) in their research on leachate Pollution of Soils in Enugu reported that all the heavy metals tested were empirically higher than the recommended standards. Thus, careless disposal of wastes in the area giving rise to leachate that contaminated the soils. However, Ameh (2014) in his own study on evaluation of geochemical distribution of heavy metals in soil around Itakpe (iron-ore mining area) with a statistical approach reported that, soils around Itakpe have experienced various degrees of $\mathrm{Fe}, \mathrm{Pb}$, and $\mathrm{Ni}$ contamination due to geologic and anthropogenic influences. Similarly, Olatunji and Olisa (2014) studied heavy metals distribution in soils, road dust and stream sediments of the city of Ijebu-Ode, Southwestern Nigeria, with the aim to ascertain the influence of increased urbanization on the quality of the environmental media. In their work, geochemical evaluation by geoaccumulation show high concentration of $\mathrm{Cu}, \mathrm{Pb}, \mathrm{Zn}, \mathrm{Ni}, \mathrm{As}$, and $\mathrm{Cr}$ within the city centre and along the major roads when compared to the background. At the same time, Ezemokwe and Ezigbo (2016) studied heavy metal contamination in soils around Onyeama and Okpara coal mines in Enugu, Southeastern Nigeria. They discovered that soils around the Enugu coal mines exhibit characteristics that moderately affect the environment and therefore, there is health safety risk. Ezemokwe et al., (2017) studied the evaluation of heavy metal contamination of soils alongside Awka- Enugu Road, Southeastern Nigeria, to assess the heavy metal contamination in roadside top soils along the old road passing through Obioma- Nsude - Ngwo and Abor areas of Enugu State. They pointed out that, the total heavy metal concentrations of soils studied were slightly higher than previously reported levels for similar soils which suggest some degree of heavy metal pollution.

Thus, the assessment of various heavy metals from industrial and agricultural contaminated sites are essential for safety assessment of metal properties of contaminated soil. Hence, the aim of this study was to investigate the contamination of heavy metals in agricultural and industrial soils of selected areas of Enugu State.

\section{STUDY AREA}

The study area is bounded between latitudes $6^{\circ} 00^{\prime}$ and $7^{\circ} 00^{\prime} \mathrm{N}$ and longitudes $7^{\circ} 00^{\prime}$ and $8^{\circ} 00^{\prime} \mathrm{E}$ (Figure 1). It has an Area of $7,161 \mathrm{~km}^{2}$ (2,764,9 sq.m) and has total population of about 3,267,837 according to National population commission data (2006). The topography of the area is dominated by escarpment, plateau, Anambra - Imo lowland and Cross River plain. Relief of the study area ranges from 50 to $450 \mathrm{~m}$ above sea level. The highest points occur along Enugu-Okigwe cuesta. The main drainage source is the Abonyi and Anambra Rivers. All other tributaries drain into them. The area has a good natural dendritic drainage system. Enugu state is characterized by two climatic seasons, namely rainy season (April - October) and dry season (November - March). The rainy season is characterized by heavy rainfall which is accompanied by thunderstorms, heavy flooding, soil leaching, ground saturation. The average annual rainfall of the area is about $2000 \mathrm{~mm}$ (Egboka and Okpoko, 1984). The study area lies within the tropical rainforest savanna of Nigeria. 


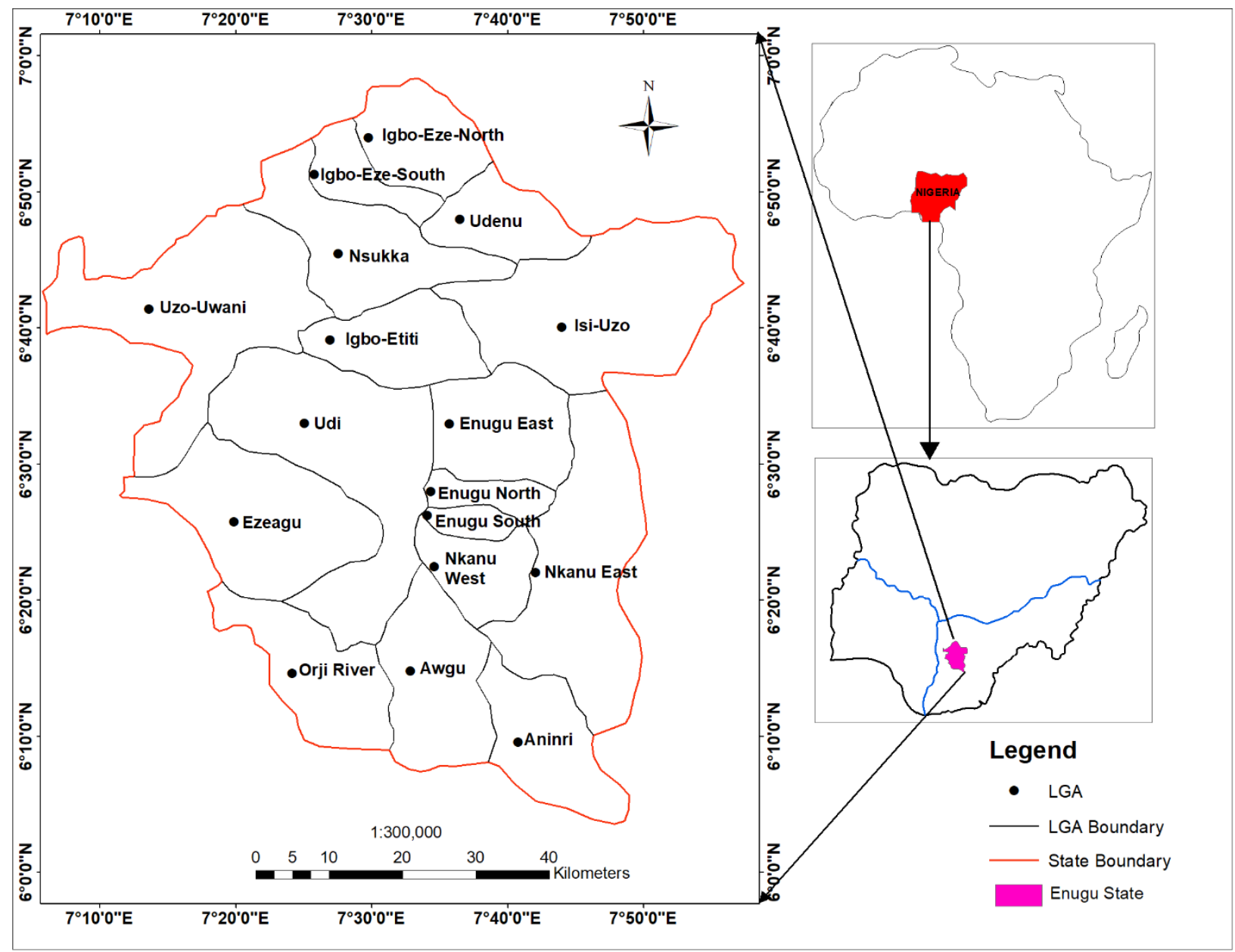

Figure 1. Location map of Enugu State

\section{GEO-HYDROLOGY OF THE STUDY AREA}

The geology and hydrogeology of Enugu area has been studied at various levels by previous researchers (Reyment, 1965; Agagu et al.,1985). The major geological formations found in the study area are (from oldest to youngest) Abakaliki Formation (Albian), Ezeaku Group (Touranian), Awgu Group (Coniacian), Nkporo Group (Campanian), Mamu Formation (Maastrichtian), Ajali Formation (Upper Maastrichtian), Nsukka Formation (Danian) and Imo Group (Paleocene) (Figure 2). The Ajali Formation is the only pronounced aquiferous formation in the study area followed by the sandy members of Awgu, Nkporo, Mamu, Nsukka and Imo Formations. Within these geological formations, several aquifer systems exist as perched, semi confined, confined and unconfined aquifer conditions (Ezeigbo and Ozoko, 1989). It is well documented that perched aquifers exist over the Nsukka Formation while semi confined and confined aquifers occurred within the Abakaliki, Ezeaku, Awgu, Nkporo, Mamu and Imo Formations. These aquifers are tapped by several hand dug wells and shallow boreholes at depth between $10-20 \mathrm{~m}$ in several area of the study. However, unconfined aquifer systems exist over the Ajali Formation. 


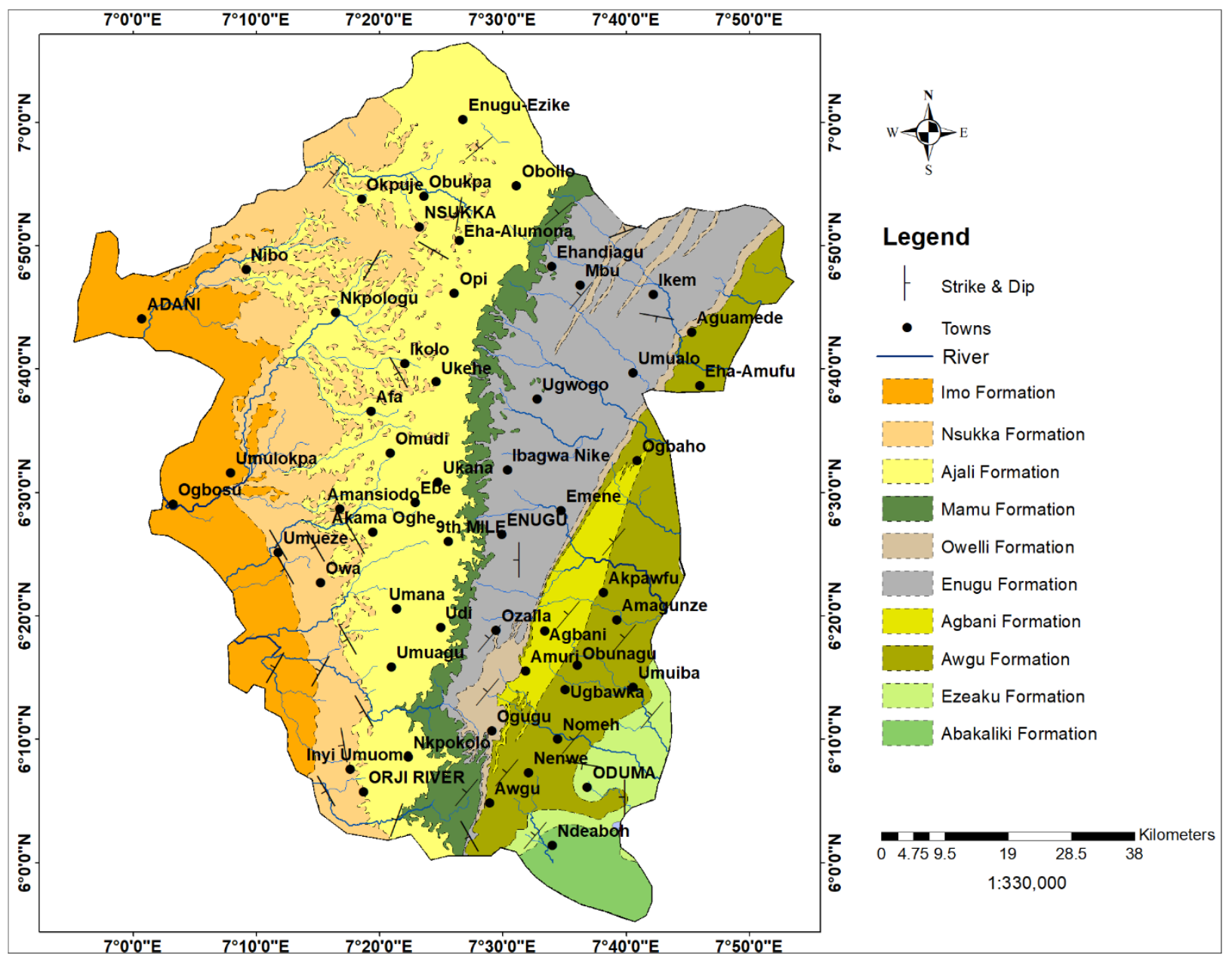

Figure 2. Geologic map of the study area

\section{MATERIALS AND METHODS}

The scope of the sampling area is limited to selected agricultural and industrial sites of Enugu State. A total of 60 soil samples were collected from dumpsites (2), industrial soils (20), wetlands (12), mechanic workshops (3), roadsides (10), river beds (10) and control samples (3) (Table 1). At each sampling site, soil samples were collected separately by random selection, from surface $(0.5 \mathrm{~m}$ soil layer) with a small core sampler. The soil samples collected were found to be in wet condition. The collected soil samples were stored in polyethylene bags for transport and storage. The soil samples were air-dried in an oven at $50^{\circ} \mathrm{C}$ for 3 days. They were then sieved through a $2.0-\mathrm{mm}$ polyethylene sieve to remove stones, coarse materials and other debris. Portions of the soil samples ( 20 g) were ground in a mechanical agate grinder until fine particles $(<200 \mu \mathrm{m})$ were obtained.

Heavy metals such as, $\mathrm{Fe}, \mathrm{Mn}, \mathrm{Cd}, \mathrm{As}, \mathrm{Cu}, \mathrm{Cr}, \mathrm{Ni}, \mathrm{Pb}$, and $\mathrm{Zn}$ were determined by acid digestion method as described by Wong and $\mathrm{Li}$, 2003. The heavy metal concentrations of the solutions were determined using Atomic absorption spectrophotometer Buck Scientific 200 following the standard procedures as given in APHA (1995). Duplicates of all the analyzed samples were done.

Table 1. Summary of sample collection

\begin{tabular}{|c|c|c|c|c|c|c|c|}
\hline Sample Type & $\begin{array}{l}\text { Enugu } \\
\text { area } N= \\
25\end{array}$ & $\begin{array}{l}\text { Nsukka } \\
\text { area } N=7\end{array}$ & $\begin{array}{l}\text { Adani area } \\
N=6\end{array}$ & $\begin{array}{l}\text { Ikem area } \\
N=6\end{array}$ & $\begin{array}{l}\text { Oduma } \\
\text { area } N=7\end{array}$ & $\begin{array}{l}\text { Oji River } \\
\text { area } N=6\end{array}$ & $\begin{array}{l}\text { Control } \\
\text { Imiliki-agu } \\
\text { samples } \mathbf{N}=3\end{array}$ \\
\hline Dumpsite & 1 & 1 & - & - & - & - & - \\
\hline
\end{tabular}




\begin{tabular}{|l|l|l|l|l|l|l|l|}
\hline Industry & 15 & 2 & - & - & - & 3 & - \\
\hline Wetland & - & - & 4 & 4 & 4 & - & - \\
\hline Mechanic W. & 2 & 1 & - & - & - & - & - \\
\hline Roadside & 3 & 2 & 1 & 1 & 1 & 1 & 1 \\
\hline River bed & 3 & - & 1 & 1 & 2 & 1 & 2 \\
\hline Animal dung & 1 & 1 & - & - & - & 1 & - \\
\hline
\end{tabular}

\section{RESULTS AND DISCUSION}

The results of the heavy metal analysis of soils from dumpsites, industries, wetlands, mechanic workshops, roadsides, river beds, animal dungs and control samples were presented for both wet and dry seasons. The values obtained for iron, manganese, arsenic, lead, zinc, cadmium, chromium, nickel and copper were clearly tabulated (Table 2 and 3). The values obtained in the study were compared with Food and Agricultural Organization and World Health Organization for industrial and agricultural soils (FAO/WHO, 2011). The distribution of mean metal concentrations in the soil samples was found in the order of $\mathrm{Fe}^{3+}>\mathrm{Zn}>\mathrm{Mn}>\mathrm{Cr}>\mathrm{As}>\mathrm{Pb}>$ $\mathrm{Cd}>\mathrm{Ni}>\mathrm{Cu}$. 
Table 2. Descriptive statistics of heavy metals measured in the wet season

\begin{tabular}{|c|c|c|c|c|c|c|c|c|c|c|}
\hline Source & Statistics & $\mathrm{Fe}^{3+}$ & Mn & As & $\mathbf{P b}$ & Zn & Cd & $\mathrm{Cr}$ & $\mathbf{N i}$ & $\mathbf{C u}$ \\
\hline \multirow[t]{3}{*}{ Dumpsite } & Min. & 110.9 & 15.3 & 18.4 & 28.3 & 56.8 & 0.002 & 8.52 & 6.92 & 5.47 \\
\hline & Max. & 636.0 & 78.1 & 78.3 & 161.6 & 620.1 & 4.023 & 228.52 & 58.23 & 145.21 \\
\hline & Mean & 373.45 & 46.7 & 48.35 & 94.95 & 338.45 & 2.013 & 118.52 & 32.58 & 75.34 \\
\hline \multirow{3}{*}{$\begin{array}{l}\text { Industrial } \\
\text { Soils }\end{array}$} & Min. & 163.8 & 43.2 & 25.1 & 45.9 & 46.5 & 0.002 & 28.07 & 8.52 & 15.10 \\
\hline & Max. & 867.43 & 123.8 & 59.6 & 127.8 & 803.6 & 2.031 & 196.34 & 28.26 & 86.32 \\
\hline & Mean & 515.62 & 83.5 & 42.35 & 86.85 & 425.05 & 1.017 & 112.21 & 18.39 & 50.71 \\
\hline \multirow{3}{*}{$\begin{array}{l}\text { Wetland } \\
\text { Soils }\end{array}$} & Min. & 98.6 & 16.5 & 20.6 & 23.7 & 38.7 & 0.001 & 20.12 & 9.43 & 10.11 \\
\hline & Max. & 205.3 & 38.7 & 68.2 & 133.0 & 596.4 & 1.501 & 178.45 & 46.13 & 97.31 \\
\hline & Mean & 151.95 & 27.6 & 44.40 & 78.35 & 317.55 & 0.751 & 99.29 & 27.78 & 53.71 \\
\hline \multirow[t]{3}{*}{ Mechanic Workshop } & Min. & 109.5 & 12.4 & 12.9 & 30.6 & 92.8 & 0.001 & 28.07 & 6.23 & 3.47 \\
\hline & Max. & 153.1 & 36.0 & 57.3 & 125.4 & 481.1 & 0.912 & 137.99 & 67.09 & 56.87 \\
\hline & Mean & 131.3 & 24.2 & 35.10 & 78.0 & 286.95 & 0.457 & 83.03 & 36.68 & 30.17 \\
\hline \multirow[t]{3}{*}{ Roadside } & Min. & 155.6 & 25.0 & 18.7 & 30.6 & 83.4 & 0.021 & 10.51 & 5.45 & 6.32 \\
\hline & Max. & 286.3 & 40.3 & 75.23 & 130.9 & 491.7 & 1.405 & 182.12 & 91.36 & 78.30 \\
\hline & Mean & 220.95 & 32.7 & 46.97 & 80.75 & 281.55 & 0.713 & 96.32 & 48.41 & 42.31 \\
\hline \multirow[t]{3}{*}{ River bed } & Min. & 116.2 & 11.7 & 10.2 & 27.8 & 123.3 & 0.003 & 28.07 & 6.92 & 10.11 \\
\hline & Max. & 205.8 & 52.6 & 40.3 & 98.4 & 492.1 & 1.021 & 173.24 & 38.14 & 86.32 \\
\hline & Mean & 161.0 & 32.2 & 25.25 & 63.1 & 307.7 & 0.512 & 100.66 & 22.53 & 48.22 \\
\hline
\end{tabular}




\begin{tabular}{|c|c|c|c|c|c|c|c|c|c|c|}
\hline \multirow[t]{3}{*}{ Animal dung } & Min. & 86.9 & 9.6 & 6.3 & 51.2 & 87.3 & 0.011 & 96.21 & 6.0 & 3.47 \\
\hline & Max. & 231.6 & 52.8 & 35.5 & 162.0 & 381.4 & 2.118 & 107.53 & 28.7 & 96.01 \\
\hline & Mean & 159.3 & 31.2 & 20.9 & 106.6 & 234.35 & 1.065 & 101.87 & 17.35 & 49.74 \\
\hline \multirow[t]{3}{*}{ Control samples } & Min. & 100.2 & 10.2 & 8.7 & 28.7 & 121.0 & 0.001 & 56.9 & 5.21 & 5.71 \\
\hline & Max. & 115.4 & 25.9 & 52.2 & 73.9 & 336.9 & 0.843 & 90.1 & 27.18 & 62.30 \\
\hline & Mean & 107.8 & 18.05 & 30.45 & 51.3 & 228.95 & 0.422 & 73.5 & 16.19 & 30.01 \\
\hline FAO/WHO (2011) & & 300 & 20 & 40 & 85 & 300 & 0.8 & 100 & 35 & 73 \\
\hline
\end{tabular}

Table 3. Descriptive statistics of heavy metals measured in the dry season

\begin{tabular}{|c|c|c|c|c|c|c|c|c|c|c|}
\hline Source & Statistics & $\mathrm{Fe}^{3+}$ & Mn & As & $\mathbf{P b}$ & Zn & Cd & $\mathrm{Cr}$ & Ni & $\mathrm{Cu}$ \\
\hline \multirow[t]{3}{*}{ Dumpsite } & Min. & 100.1 & 10.9 & 18.0 & 26.6 & 58.3 & 0.001 & 8.12 & 6.09 & 4.14 \\
\hline & Max. & 726.2 & 70.9 & 73.3 & 160.0 & 629.5 & 4.003 & 230.14 & 58.30 & 132.20 \\
\hline & Mean & 413.2 & 40.9 & 45.7 & 93.3 & 343.9 & 2.002 & 119.13 & 32.20 & 68.17 \\
\hline \multirow{3}{*}{$\begin{array}{l}\text { Industrial } \\
\text { Soils }\end{array}$} & Min. & 157.1 & 40.6 & 25.3 & 40.6 & 51.2 & 0.001 & 20.12 & 9.12 & 15.11 \\
\hline & Max. & 1000.3 & 163.1 & 55.2 & 151.6 & 813.2 & 3.011 & 123.04 & 20.20 & 80.12 \\
\hline & Mean & 578.7 & 101.9 & 40.3 & 96.1 & 432.2 & 1.506 & 71.58 & 14.66 & 47.62 \\
\hline \multirow{3}{*}{$\begin{array}{l}\text { Wetland } \\
\text { Soils }\end{array}$} & Min. & 80.1 & 15.3 & 20.8 & 22.7 & 35.0 & 0.001 & 21.15 & 10.73 & 10.01 \\
\hline & Max. & 215.0 & 40.7 & 65.1 & 138.5 & 506.9 & 1.609 & 180.41 & 41.11 & 84.23 \\
\hline & Mean & 147.6 & 28.0 & 42.9 & 80.1 & 270.9 & 0.805 & 100.78 & 25.92 & 47.12 \\
\hline Mechanic Workshop & Min. & 110.2 & 12.9 & 12.0 & 31.1 & 92.3 & 0.001 & 28.11 & 6.30 & 3.40 \\
\hline
\end{tabular}




\begin{tabular}{|l|l|l|l|l|l|l|l|l|l|l|}
\hline & Max. & 155.1 & 36.8 & 52.6 & 130.0 & 482.3 & 0.900 & 137.04 & 70.39 & 56.17 \\
\cline { 2 - 10 } & Mean & 132.7 & 24.9 & 32.3 & 80.6 & 287.3 & 0.451 & 82.58 & 38.35 & 29.79 \\
\hline Roadside & Min. & 87.4 & 25.0 & 20.2 & 30.6 & 83.4 & 0.021 & 10.51 & 5.45 & 6.32 \\
\cline { 2 - 10 } & Max. & 213.9 & 40.3 & 38.4 & 130.9 & 491.7 & 1.405 & 182.12 & 91.36 & 78.30 \\
\cline { 2 - 10 } & Mean & 150.7 & 32.7 & 29.3 & 80.8 & 281.6 & 0.713 & 96.32 & 48.41 & 42.31 \\
\hline River bed & Min. & 155.6 & 11.7 & 10.2 & 30.5 & 121.0 & 0.001 & 96.21 & 6.92 & 10.11 \\
\cline { 2 - 10 } & Max. & 286.3 & 52.6 & 40.3 & 127.6 & 336.9 & 1.102 & 107.53 & 38.14 & 86.32 \\
\cline { 2 - 10 } & Mean & 220.9 & 32.2 & 25.25 & 79.05 & 228.9 & 0.552 & 101.87 & 22.53 & 48.22 \\
\hline Animal dung & Min. & 116.2 & 15.0 & 18.7 & 41.0 & 123.3 & 0.011 & 28.07 & 6.02 & 3.47 \\
\cline { 2 - 10 } & Max. & 205.8 & 48.9 & 75.23 & 149.3 & 492.1 & 2.118 & 173.24 & 40.8 & 96.01 \\
\cline { 2 - 9 } & Mean & 161.0 & 31.9 & 46.97 & 95.2 & 307.7 & 1.065 & 100.66 & 23.41 & 49.74 \\
\hline Control samples & Min. & 100.2 & 10.2 & 8.7 & 21.4 & 98.7 & 0.001 & 36.01 & 5.21 & 8.92 \\
\cline { 2 - 9 } & Max. & 115.4 & 25.9 & 52.2 & 66.2 & 281.3 & 0.843 & 125.9 & 27.18 & 85.32 \\
\hline
\end{tabular}


The mean level of Fe in the soil samples ranged from $107.8-515.62 \mathrm{mg} / \mathrm{kg}$ in the rainy season while the dry season varied from 107.8 to $578.7 \mathrm{mg} / \mathrm{kg}$. Some of the soil samples except dumpsite and industrial soils lie below the standard limit of $300 \mathrm{mg} / \mathrm{kg}$ as recommended by FAO/WHO (2011). The higher values $\mathrm{Fe}^{3+}$ recorded in the dumpsite and industrial soils could be as a result of discarded plastics, aerosols, juice cans and industrial effluents discharge along channel that leached into the soil. The mean level of Mn fluctuates between 18.05 to $83.5 \mathrm{mg} / \mathrm{kg}$ in the wet season and lower than values of $18.1-101.9 \mathrm{mg} / \mathrm{kg}$ recorded in the dry season. The general values of Mn for both seasons are above permissible limit of $20 \mathrm{mg} / \mathrm{kg}$ recommended by FAO/WHO (2011) except the control samples. Average values for arsenic varied from 25.25 to $48.35 \mathrm{mg} / \mathrm{kg}$ in the wet season and from $25.25-46.97 \mathrm{mg} / \mathrm{kg}$ in the dry season. The mean values of arsenic above $40 \mathrm{mg} / \mathrm{kg}$ limit for industrial and agricultural soils as stipulated by FAO/WHO (2011) was observed in the animal dungs, dumpsites, wetlands and industrial soils. Agricultural chemical fertilizers, pesticides and industrial wastes related to production materials could lead to the arsenic contamination of industrial and agricultural soils of the area. The mean concentration of $\mathrm{Pb}$ ranged from $51.3-106.6 \mathrm{mg} / \mathrm{kg}$ in the wet season and $51.3-106.6 \mathrm{mg} / \mathrm{kg}$ in the dry season. Nearly all lead values for both seasons lie below the limit of $80 \mathrm{mg} / \mathrm{kg}$ as recommended by FAO/WHO (1998) except samples collected from dumpsite, industrial and animal dung soils. High concentration of lead in the soils from dumpsites, industries and animal dungs for both wet and dry seasons could be as a result of their sources from automobile exhaust fumes as well as dry lead batteries, sewage industrial effluents, discarded plastics and other metal related wastes. In this study, the mean levels of $\mathrm{Zn}$ varied from 228.95 to $425.05 \mathrm{mg} / \mathrm{kg}$ in the wet season and from 228.9 to $432.2 \mathrm{mg} / \mathrm{kg}$ in dry season. The guideline value of zinc is $300 \mathrm{mg} / \mathrm{kg}$ for industrial and agricultural soils according to FAO/WHO (2011). Zinc concentration in dumpsite, river bed, animal dung and industrial soils have exceeded maximum limit for wet and dry seasons respectively, hence, it is a potential health risk to human and animals. The mean concentration of cadmium in all the soil samples were found in trace amounts ranging from $2.013-0.422 \mathrm{mg} / \mathrm{kg}$ in the wet season and these values are higher than the mean levels of $2.002-0.422 \mathrm{mg} / \mathrm{kg}$ in dry season. The values of the mean concentrations obtained for both season are all below the maximum tolerable level of $0.8 \mathrm{mg} / \mathrm{kg}$ as stipulated by FAO/WHO (2011) for the industrial and agricultural soils. For Cr, the mean levels in the soil samples ranged from 83.03 to $118.52 \mathrm{mg} / \mathrm{kg}$ in the rainy season which was slightly higher, as compared to the mean level of dry season $(71.58$ to $119.13 \mathrm{mg} / \mathrm{kg}$ ). But they are higher than the standard permissible level which is $100 \mathrm{mg} / \mathrm{kg}$ for industrial and agricultural soils as recommended by FAO/WHO (2011). Sources of Cr in the soils could be due to waste consisting of lead-chromium batteries, discarded plastics and empty paint containers.

Nickel had mean values ranged from 16.19 to $48.41 \mathrm{mg} / \mathrm{kg}$ in rainy season and from 14.66 to $48.41 \mathrm{mg} / \mathrm{kg}$ in the dry season. Nickel concentration is observed to be higher than $35 \mathrm{mg} / \mathrm{kg}$ (FAO/WHO, 2011) within the mechanic workshop soils. The elevated values of Ni from mechanic workshop soils for both wet and dry seasons could be attributed to used engine oil, lubricant and automated batteries. Mean copper concentration in industrial and agricultural soils ranges from $30.17-75.34 \mathrm{mg} / \mathrm{kg}$ in the wet season and higher than $29.79-68.17 \mathrm{mg} / \mathrm{kg}$ in the dry season (Figure $1 \& 2$ ) though these values were within the maximum permissible limits of 73 $\mathrm{mg} / \mathrm{kg}$ except in the wet season where $75.34 \mathrm{mg} / \mathrm{kg}$ was recorded within the dumpsite soils.

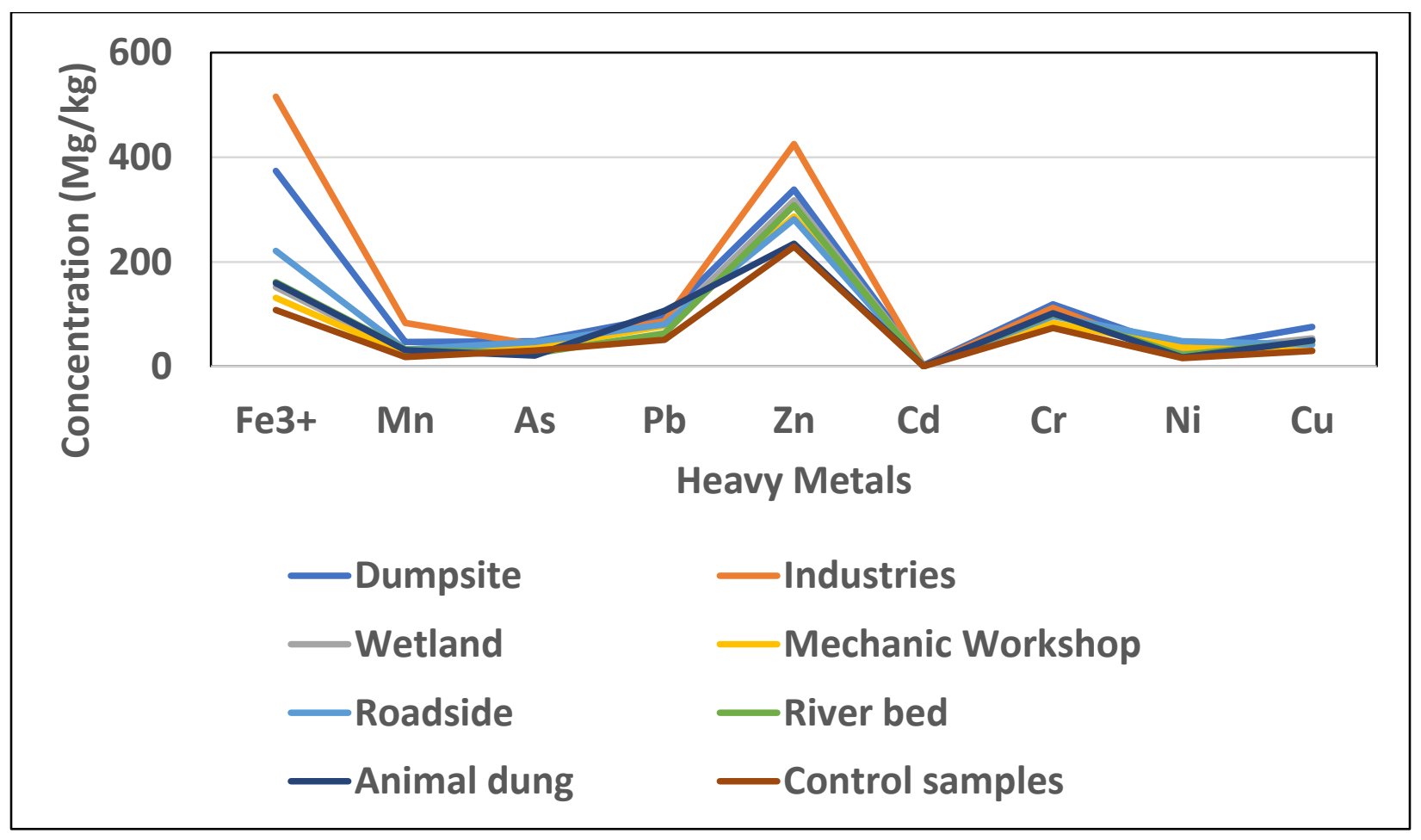

Figure 1. Distribution of values for $\mathrm{Fe}, \mathrm{Mn}, \mathrm{As}, \mathrm{Pb}, \mathrm{Zn}, \mathrm{Cd}, \mathrm{Cr}$, $\mathrm{Ni}$ and $\mathrm{Cu}$ during the wet season 


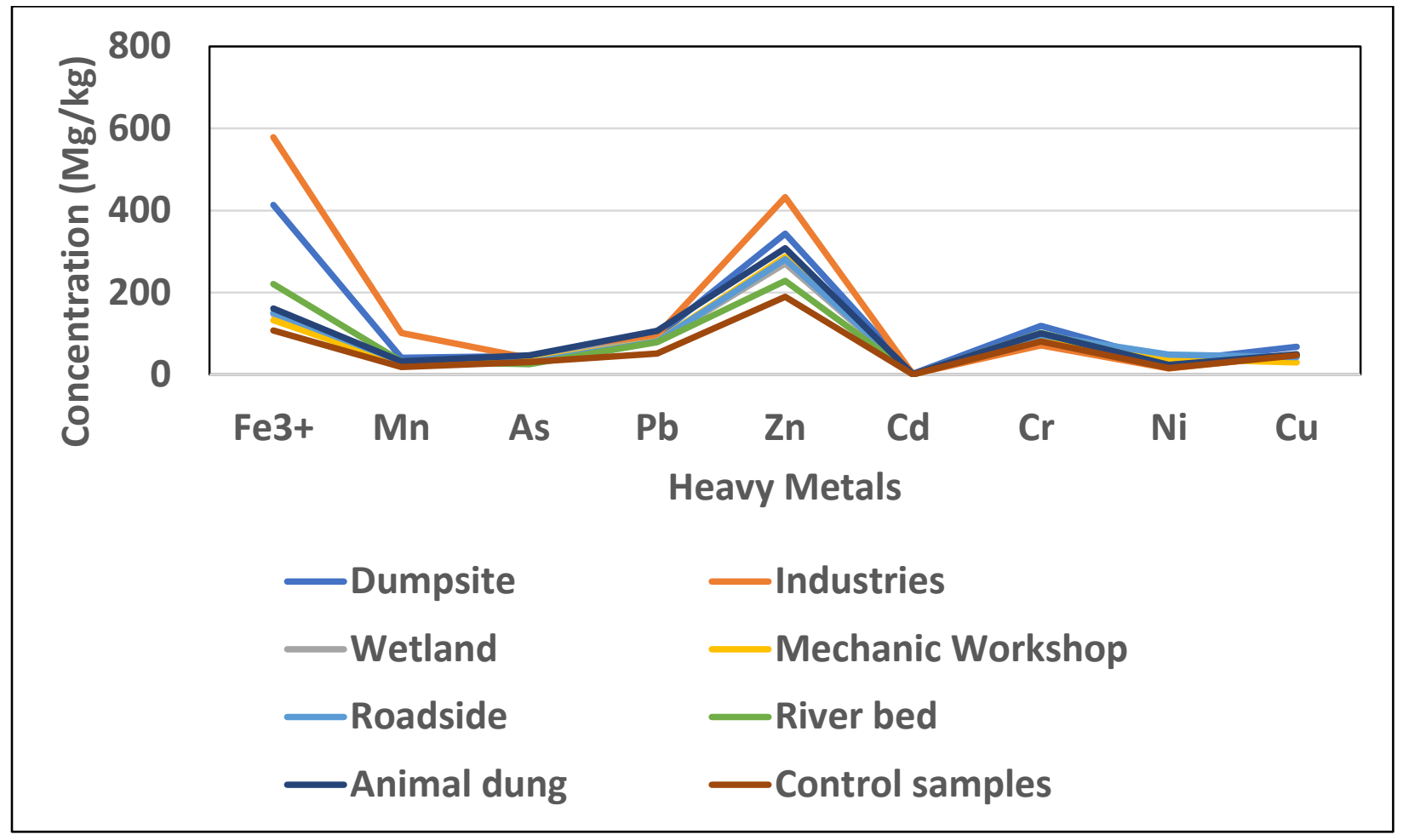

Figure 2. Distribution of values for $\mathrm{Fe}, \mathrm{Mn}, \mathrm{As}, \mathrm{Pb}, \mathrm{Zn}, \mathrm{Cd}, \mathrm{Cr}, \mathrm{Ni}$ and $\mathrm{Cu}$ during the dry season

\section{CORRELATION MATRIX}

From the Pearson correlation matrix, the values of (r) can be classified into positive high and low as well as negative high and low correlations for both seasons. A high positive correlation values was observed for the parameters of $\mathrm{Mn}$ and $\mathrm{Fe} ; \mathrm{Zn}$ and $\mathrm{Fe} ; \mathrm{Zn}$ and $\mathrm{Mn} ; \mathrm{Cu}$ and $\mathrm{Cd}$; as well as $\mathrm{Cu}$ and $\mathrm{Cr}$ which indicates the strong relation between these variables. A low positive correlation values was observed for the parameters of $\mathrm{Cu}-\mathrm{As}, \mathrm{Cr}-\mathrm{Cd}$, As $-\mathrm{Mn}, \mathrm{Zn}-\mathrm{As}, \mathrm{Cu}-\mathrm{Zn}, \mathrm{Cu}-\mathrm{Pb}, \mathrm{Cr}-\mathrm{As}, \mathrm{Ni}-\mathrm{Pb}$ and $\mathrm{Pb}-\mathrm{As}$. The second type of correlation values which is highly negative correlation observed for the parameters, $\mathrm{Cr}-\mathrm{Mn}$ and $\mathrm{Cr}-\mathrm{Zn}$, which indicates the strong relation between these variables, also the low negative correlation for $\mathrm{Ni}-\mathrm{Fe}, \mathrm{Cu}-\mathrm{Ni}, \mathrm{Cr}-\mathrm{Fe}, \mathrm{Ni}-\mathrm{Zn}, \mathrm{Ni}-\mathrm{Fe}, \mathrm{Ni}-\mathrm{Cd}$ and $\mathrm{Cr}-\mathrm{Pb}$ were obtained (Table $4 \& 5$ ).

Table 4. Correlation matrix of heavy metals of the soil samples during the wet season.

\begin{tabular}{lrrrrrrrrr}
\hline & \multicolumn{1}{c}{$\mathrm{Fe} 3+$} & \multicolumn{1}{c}{$\mathrm{Mn}$} & \multicolumn{1}{c}{$\mathrm{As}$} & $\mathrm{Pb}$ & $\mathrm{Zn}$ & $\mathrm{Cd}$ & $\mathrm{Cr}$ & $\mathrm{Ni}$ & $\mathrm{Cu}$ \\
\hline $\mathrm{Fe} 3+$ & 1.00 & & & & & & & & \\
$\mathrm{Mn}$ & $0.96^{*}$ & 1.00 & & & & & & & \\
$\mathrm{As}$ & 0.43 & 0.25 & 1.00 & & & & & & \\
$\mathrm{~Pb}$ & 0.15 & 0.15 & -0.53 & 1.00 & & & & & \\
$\mathrm{Zn}$ & $0.90^{*}$ & $0.96^{*}$ & 0.20 & 0.14 & 1.00 & & & & \\
$\mathrm{Cd}$ & 0.53 & 0.35 & 0.30 & 0.59 & 0.34 & 1.00 & & & \\
$\mathrm{Cr}$ & 0.79 & 0.68 & 0.41 & 0.47 & 0.69 & 0.87 & 1.00 & & \\
$\mathrm{Ni}$ & -0.40 & -0.55 & 0.40 & -0.47 & -0.72 & -0.22 & -0.43 & 1.00 & \\
$\mathrm{Cu}$ & 0.50 & 0.33 & 0.46 & 0.43 & 0.38 & $0.93^{*}$ & $0.90^{*}$ & -0.26 & 1.00 \\
\hline
\end{tabular}

Table 5. Correlation matrix of heavy metals of the soil samples during the dry season. 


\begin{tabular}{lrrrrrrrrr}
\hline & \multicolumn{1}{c}{$\mathrm{Fe} 3+$} & \multicolumn{1}{c}{$\mathrm{Mn}$} & \multicolumn{1}{c}{$\mathrm{As}$} & \multicolumn{1}{c}{$\mathrm{Pb}$} & $\mathrm{Zn}$ & $\mathrm{Cd}$ & $\mathrm{Cr}$ & $\mathrm{Ni}$ & $\mathrm{Cu}$ \\
\hline $\mathrm{Fe} 3+$ & 1.00 & & & & & & & & \\
$\mathrm{Mn}$ & $0.92^{*}$ & 1.00 & & & & & & & \\
$\mathrm{As}$ & 0.46 & 0.26 & 1.00 & & & & & & \\
$\mathrm{~Pb}$ & 0.47 & 0.47 & 0.03 & 1.00 & & & & & \\
$\mathrm{Zn}$ & $0.94^{*}$ & $0.94 *$ & 0.26 & 0.68 & 1.00 & & & & \\
$\mathrm{Cd}$ & 0.81 & 0.58 & 0.41 & 0.63 & 0.75 & 1.00 & & & \\
$\mathrm{Cr}$ & -0.27 & -0.59 & 0.16 & -0.09 & -0.43 & 0.27 & 1.00 & & \\
$\mathrm{Ni}$ & -0.24 & -0.39 & 0.45 & 0.04 & -0.26 & -0.17 & 0.17 & 1.00 & \\
$\mathrm{Cu}$ & 0.44 & 0.15 & 0.33 & 0.17 & 0.25 & 0.78 & 0.70 & -0.28 & 1.00 \\
\hline
\end{tabular}

\section{CONCLUSION}

Soil samples from dumpsites, industries, wetlands, mechanic workshops, roadsides, river beds, animal dung in Enugu State, Southeastern, Nigeria were collected for two seasons, wet and dry to examine the concentration of Iron, Manganese, Arsenic, Lead, Zinc Cadmium, Chromium, Nickel and Copper. The observed values of $\mathrm{Fe}, \mathrm{Cd}$, As, and $\mathrm{Pb}$ are well above the recommended values as prescribed by FAO/WHO for industrial and agricultural soils. The overall results highlight that soils from industrial and farmlands are responsible for polluting the surrounding environment. From correlation matrix point of view, high positive correlations were observed between $\mathrm{Mn}$ and $\mathrm{Fe} ; \mathrm{Zn}$ and $\mathrm{Fe} ; \mathrm{Zn}$ and $\mathrm{Mn} ; \mathrm{Cu}$ and $\mathrm{Cd}$; as well as $\mathrm{Cu}$ and $\mathrm{Cr}$ during the wet season and these suggests the strong relation between these variables. However, during the dry season, high positive correlations were depicted among Mn and Fe; $\mathrm{Zn}$ and $\mathrm{Fe} ; \mathrm{Zn}$ and $\mathrm{Mn}$ indicating strong relation among the variables and pointed out that soils' deterioration was associated with industrial and agricultural activities. These findings suggest that there is need for urgent attention to proffer far reaching solutions to the problems of the exposed contaminated sites. Further research should be carried out on hydrogeochemical studies to ascertain the status of groundwater quality of the study area.

\section{REFERENCES}

Adewara AO, Akinlolu A (2007). Contamination indices and heavy metal concentrations in Urban soils of Ibadan metropolis, Southwestern, Nigeria. J. Soc. Environ. Geoch. Heal. 30(3), 243 254.

Agagu OK, Fayose, EA, Petters SW (1985). Stratigraphy and sedimentation in the Senonian Anambra Basin of eastern Nigeria. J. Min. Geol. 22 (1), 26-36.

Ahmadipour F, Bahramifar N, Ghasempouri SM (2014). Fractionation and mobility of cadmium and lead in soils of Amol area in Iran, using the modified BCR sequential extraction method. Chem. Specia. and Bio. 26(1), 31-36.

Ameh EG (2014). Geochemical distributions of heavy metals in soils around Itakpe-Iron ore mining area. A statistical approach. Res. J. Environ. Earth Sci., 6(3), 118-126.

APHA (1995). American Public Health Association. Standard Methods for the Examination of Water and Waste Water, 19th edn. APHA-AWWA-WPCF, Washington, DC. p. 525-987.

Assah VA, Abimbola AF, Such CE (2003). Heavy metal concentration and distribution on surface soils of the Rassa Industrial Zone I Dounal Cameroon. Arabia. J. Sci. Eng. 31(24), 147-158.

Ekere NR, Ukoha OP (2013). Heavy metals in street soil dusts of industrial market in Enugu, South East, Nigeria. Int. J. Phy. Sci. 8(4), 175-178

Elanzer AA, Salman AS, Seleem EM, Abu El Ella EM (2015). Assessment of some heavy metals pollution and bioavailability in roadside soil of Alexandria-Marsa Matruh Highway, Egipt. Int. J. Eco.

Ezeigbo HI, Ozoko DC (1989). An Evaluation of the Water Resources of Nsukka and environs, Anambra State, Nigeria. Wat. Res. J. Nig. Asso. Hydrogeo. 2, 20-25.

Ezemokwe DE, Ichu CB, Okoro JN, Opara AI (2017). Evaluation of heavy metal contamination of Soils alongside Awka- Enugu Road, Southeastern Nigeria. Asian J. Environ. Eco., 4(1), $1-11$.

Kelly J, Thornton I, Simpson P (1996). Urban geochemistry: A study of the influence of anthropogenic activity on the heavy metal content of soils in traditionally industrial and nonindustrial areas of Britain. Appl. Geo. chem. 11, 363-370.

National Population Commission of Nigeria (NPC) (2006). Population and Housing Census Result. NPC, Lagos. p. 26. 
Njoku PC, Ayoka AO (2007). Evaluation of heavy metal pollutants from soils at municipal solid waste deposit in Owerri, Imo State, Nigeria. Journal Chemical Society of Nigeria 32(1), 5760.

Nouri M, Haddioui A (2016). Assessment of metals conatmiantion and ecological risk in Ait Ammar Abandoned Iron mine soil, Morocco. Ekologia (Baratislava) 35(1), 32-49.

Okafor CC, Onwuka SU (2013). Leachate Pollution of Soil of Enugu. J. Environ. Sci. Toxico. Food Tech., 5: 41-47.

Olatunji OS, Osibanj O (2012). Baseline studies of some heavy metals in top soils around the iron-ore mining field at Itakpe-Okene, North-Central Nigeria. Int. J. Min. Eng. Min. Proc.,1(3), 107-114.

Osakwe SA (2010). Distribution of Heavy metals in soils around automobile dumpsites in Agbo and Environs, Delta State, Nigeria. J. Chem. Soc. Nig. 35(1), 53-60.

Ottensen RT, Langedal M (2001). Urban geochemistry in Trondheim, Norway. Norges Geologiske Undersokeise, Bulletin, 438: 63-69.

Reyment RA (1965). Aspects of the Geology of Nigeria, University of Ibadan, Nigeria. p. 145.

Sharma RK, Agraval M, Marshal F (2007). Heavy metal contamination of soils and vegetables in sub urban areas of Varansi, India. Ecotoxicol. Environ. Safety 66, 258-266.

Xiangdong L, Siu-lan L, Sze-chung W, Wenzhong S, Iain T (2010). The study of metal contamination in urban soils of Hong Kong using a GIS-based Approach. Applied Geochemistry 16, 1371-13688.

FAO/WHO (2011). Joint FAO/WHO food standards programme codex committee on contaminants in foods, fifth. Session, 64-89. 